\title{
Efficacy of Fungicide and Bio-Control Agents against Root Rot of Black Gram (Vigna mungo L.) caused by Macrophomina phaseolina (Tassi) Goid
}

\author{
K. Athira* \\ Department of Plant Pathology, Tamil Nadu Agricultural University, \\ Coimbatore-641003, Tamil Nadu, India \\ *Corresponding author
}

\section{A B S T R A C T}

\begin{tabular}{|l|}
\hline Ke y w or d s \\
Charcoal rot, Black \\
gram, M. \\
Phaseolina, \\
Trichoderma viride, \\
Pseudomonas \\
fluorescens, \\
Carbendazim.
\end{tabular}

The charcoal rot of Black gram caused by Macrophomina phaseolina (Tassi) Goid. is an important disease affecting Black gram production areas in India. Although considerable research related to the biology and ecology of Macrophomina has been conducted, it continues to cause huge economic losses in many crops. No single control measures are effective or not feasible under farmer's conditions. In this study, two bio-control agents, Trichoderma viride and Pseudomonas fluorescens were assessed for their ability to reduce the growth of $M$. phaseolina under laboratory conditions. It was found that among the antagonists tested, Trichoderma exhibited strong inhibition (77.77\%) against $M$. phaseolina. Their culture filtrates were also found to be effective in promoting the in vitro growth. The maximum seed germination (97\%), shoot length $(22.2 \mathrm{~cm})$ and root length $(16.5 \mathrm{~cm})$ was recorded in the seed treatment of Trichoderma followed by Pseudomonas in the decreasing merit. In addition to the use of the bio-control agents, fungicide Carbendazim was also applied as seed treatment at recommended doses. The results indicated that Carbendazim @ 0.1\% was very effective in the management of root rot disease which effectively controlled the mycelial growth.

\section{Introduction}

Vigna mungo commonly referred to as urd bean, black gram, black lentil or white lentil is a bean grown in southern Asia. Black gram is very nutritious as it contains high levels of proteins, potassium, calcium, iron, niacin (B3), thiamine (B1) and Riboflavin (B2). Black gram has received prominence in Indian diet especially for culinary preparation of dal, Idli, Vada, Dosa and pappad. Black gram has been shown to be useful in mitigating elevated cholesterol levels. India is the world's largest producer and consumer of black gram. India produces about 1.5 to 1.9 million tonnes of black gram annually from about 3.5 million hectares of area, with an average productivity of $500 \mathrm{~kg}$ per hectare. Black gram output accounts for about 10 per cent of India's total pulse production.

Root rot caused by Macrophomina phaseolina (Tassi) Goid is one of the most important fungal diseases of Black gram. It inflicts series economic loss to the crop. It was reported to result in a loss of 28.6 per cent in black gram yield. It is an important disease of broad range of crops (Srivastava et al., 2001) particularly in regions with warm and dry weather conditions. M. phaseolina is reported 
to produce charcoal rot disease over 500 species of plants (Sinclair, 1982). $M$. Phaseolina is primarily soil borne in nature, with heterogeneous host specificity i.e., the ability to infect monocots as well as dicots and non-uniform distribution in the soil (Mayek-Perez et al., 2001). The pathogen is seed-borne and seed-to-seedling transmission has been documented in infected seeds (Pun et al., 1998). Macrophomina infection causes both pre- and post-emergence plant mortality. The disease symptom starts initially with yellowing and drooping of the leaves. The leaves later fall off and the plant dies within a week. Dark brown lesions are seen on the stem at ground level and bark shows shredding symptom. The affected plants can be easily pulled out leaving dried, rotten root portions in the ground. The rotten tissues of stem and root contain a large number of black minute sclerotia (Rangaswami, 1993).

The annual loss of crop production due to plant diseases alone are about 12 per cent as per the estimate of FAO. The losses are going to increase with change in agricultural practices and our country, which is tropical with warm and humid climate, provide ideal conditions for development and spread of diseases of the crop cultivated under good management systems. Therefore, control of plant disease assumes greater importance.

Protection of crop plants from diseases by using fungicides has been a widely adopted strategy and a regular practice followed for many years. However there have been many drawbacks in using chemical fungicides for managing the crop diseases. The pollution to soil, water and air caused by the accumulation of obnoxious chemical residues due to continuous use of fungicides and development of resistant strains of pathogen to these fungicides are forcing the scientists to look for methods which are eco-friendly, safe and more specific to pathogens. Chemical control of the disease is also difficult and economically not affordable for low income small scale farmers. Much of the effort to control M. phaseolina has focused on soil fumigation (Pearson et al., 1984) and applying irrigation water to reduce the disease promoting effects of drought (Kendig et al., 2000). Under above circumstances, it became inevitable to develop a bio-based, ecofriendly, biodegradable microbial antagonists in order to control plant pathogens. Biological control using antagonistic microorganisms offers a practical and economical alternative for the management of plant pathogens.

Biological control of soil borne plant pathogen by addition of antagonistic microorganism to the soil is a potential nonchemical means and is known to be a cheapest and effective method for the management of soil diseases. Biological control is eco-friendly, does not leave any residual toxicity, besides being cost effective and can be successfully exploited in the framework of integrated disease management.

Trichoderma, a saprophytic fungus is known to be one of the best candidate of biocontrol agents (Scala et al., 2007). Trichoderma species are effective biocontrol agents for several soil borne fungal plant pathogens including M. phaseolina and some species are also known for their abilities to enhance systemic resistance to plant disease as well as overall plant growth. Sundravadana (2002) reported that the seed and soil application of $T$. viride significantly controlled the blackgram root rot caused by $M$. phaseolina the biocontrol exercised by Trichoderma can occur by means of several antagonistic mechanisms such as nutrient composition, antibiotic production and mycoparasitism. Mycoparasitism has been proposed as the antagonistic mechanism displayed by Trichoderma spp. After host recognition, Trichoderma sp attaches to the host hyphae 
via coiling and penetrate the cell wall by secreting cell wall - degrading enzyme. Mycoparasites produce cell wall degrading enzymes which allow them to bore holes into its fungal host and extracts nutrients for their own growth. It also produces a large variety of volatile secondary metabolites such as ethylene, hydrogen cyanide, aldehydes and ketones which play an important role in controlling the plant pathogens (Vey et al., 2001).

Till today no single method is found to be very effective and economical for the management of dry root rot disease. Hence, an integrated approach would always ensure maximum disease suppression without any deleterious effect on the ecosystem.

Hence, integration of organic amendments along with antagonists would ensure better consistency in controlling the pathogen. Keeping the above facts in view, the present study was under taken with the following objectives

Screening of fungicide that inhibit the pathogen under in vitro

In vitro evaluation of antagonist against $M$. phaseolina

To study the plant growth promoting activity using bio control agents

\section{Materials and Methods}

\section{Isolation of the pathogen}

Macrophomina was isolated from the infected root samples by tissue segment method on Potato Dextrose Agar (PDA) and they were purified by single hyphal tip method (Rangaswami, 1993). The axenic culture of the pathogen was maintained on PDA slants and stored at $4^{\circ} \mathrm{C}$ for further study.
Efficacy of fungicide (Carbendazim) on the mycelial growth of M. phaseolina (Poisoned food technique)

The inhibitory effect of fungicide on the growth of fungi was evaluated by Poisoned Food Technique (Dhingra and Sinclair, 1985). Fungicide Carbendazim was used @ 0.01\%, $0.05 \%$ and $0.1 \%$ concentrations in autoclaved PDA medium.

Twenty $\mathrm{ml}$ of such medium was poured in each sterilized Petri plate and solidified. After solidification, $5 \mathrm{~mm}$ disc of seven days old cultures of $M$. phaseolina were cut by using sterile cork borer and placed in the centre of Petri plates containing different concentrations of fungicide and incubated at $25 \pm 1^{\circ} \mathrm{C}$.

Treatments were replicated thrice along with suitable control in which fungicide was omitted in the medium. The radial growth of M. phaseolina was measured after 7 days.

\section{Isolation of bio control agents}

The bio control agents were isolated from rhizosphere soil by serial dilution using king's B medium for Pseudomonas and PDA medium for Trichoderma (Dennis and Webster, 1971).

In vitro effect of fungal and bacterial antagonist against $M$. phaseolina (Dual culture technique)

Dual culture plate technique was used to study the antagonistic effects of Trichoderma and Pseudomonas on M. phaseolina (Kumar and Honda, 2007). Mycelial discs measuring five $\mathrm{mm}$ diameter from seven days old cultures of antagonist and the test pathogen were placed at equidistant on sterile Petri plates containing PDA medium. The Petri plates were then incubated at $28 \pm 1^{\circ} \mathrm{C}$. Three 
replications of each treatment were maintained and observed for a period of eight days. Suitable controls were kept without antagonist. Growth of the pathogenic fungi was measured at 24 hours intervals up to eight days of inoculation of antagonist. Percentage inhibition of mycelial growth of test pathogen was calculated using the formula (Vincent, 1947).

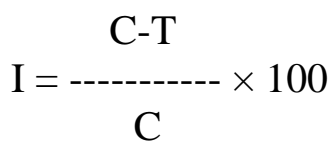

Where,

$\mathrm{I}=$ Per cent radial mycelial growth inhibition

$\mathrm{C}=$ Radial growth of pathogen in check Petriplate.

$\mathrm{T}=$ Radial growth of pathogen in dual culture .

Effect of antagonist in plant growth promotion (Roll towel method)

The plant growth-promoting activity of the bio control agents was assessed based on the seedling vigour index by the standard roll towel method (ISTA, 1993). Ten seeds were placed on presoaked germination paper. The seeds were held in position with another presoaked germination paper strip and gently pressed. The polythene sheet al.,ong with the seeds was then rolled up and incubated in a growth chamber for 10 days. Three replications were carried out for each treatment. The root length and shoot length of individual seedlings were measured and the per cent germination of the seeds was calculated. The seedling vigour index was calculated using the formula (Abdul Baki and Anderson, 1973).

Vigour Index $=($ Mean root length + Mean shoot length) $\times \%$ Germination

\section{Results and Discussion}

Efficacy of fungicide (Carbendazim) on the mycelial growth of $M$. phaseolina (Poisoned food technique)

The result showed that mycelial growth of $M$. phaseolina is arrested by Carbendazim when compared to control. Among the treatments $0.1 \%$ concentration of Carbendazim effectively controlled the mycelial growth. Percentage inhibition for $0.1 \%$ concentration is 93 per cent (Table 1). The results are in accordance with the previous work of LópezHerrera et al., (2007) and Omar et al., (2006)

\section{In vitro effect of fungal and bacterial antagonist against $M$. phaseolina (Dual culture technique)}

The results depicted in Table 2 revealed the efficiency of bio control of native isolates against $M$. phaseolina. However among the isolates tested $T$. viride found to be most effective against $M$. phaseolina, reducing the growth by 85.41 per cent when compared to control. This was followed by $P$. fluorescence reducing the growth by 83.62 per cent. Singh et al., (1999) has stated that T. viride showed antibiosis against $M$. phaseolina. $P$. fluorescens the bacterial antagonist was also effective in inhibiting the mycelial growth of M. phaseolina. In the present study the culture filtrate of $T$. viride was found to be highly inhibitory to the sclerotial germination of $M$. phaseolina.

Efficacy of bio control agent on plant growth promotion under in vitro condition (Roll towel method)

The result showed that all the native isolates of fungal and bacterial antagonists tested increased the germination per cent and increased the growth parameters of black gram seedling when compared to control (Fig. 1). 
Fig.1 Efficacy of bio control agent on plant growth promotion under in vitro condition (Roll towel method)

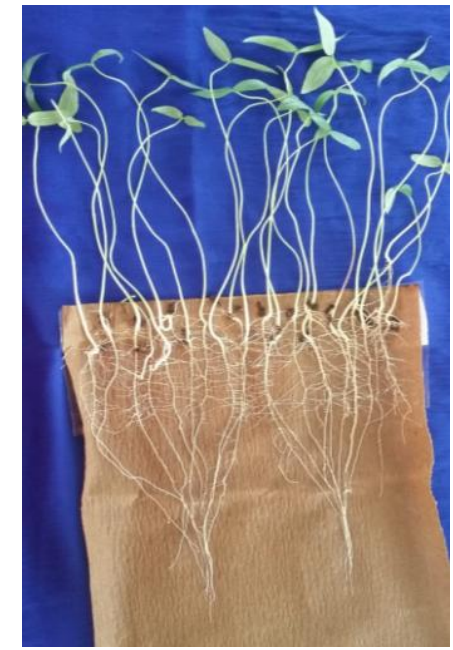

Treated

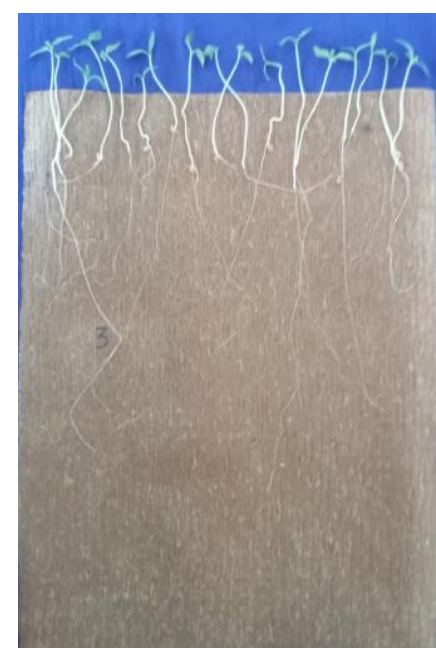

Control

Fig.2 In vitro effect of fungal and bacterial antagonists against M. phaseolina
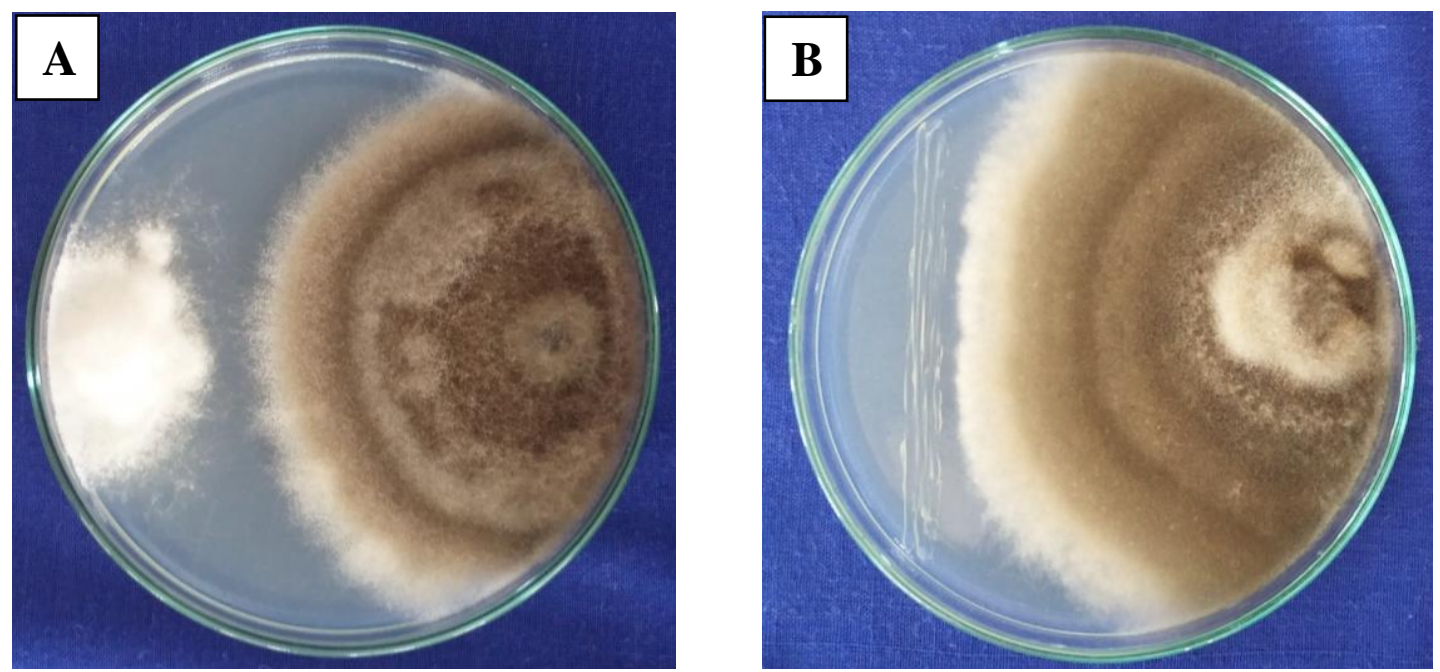

A-

Dual culture of T. viride and M. phaseolina

B- $\quad$ Dual culture of $P$. fluorescens and M. phaseolina

Table.1 Efficacy of fungicide (Carbendazim) on the mycelial growth of $M$. phaseolina (Poisoned food technique)

\begin{tabular}{|c|c|c|c|}
\hline S.No & $\begin{array}{c}\text { Concentration of culture } \\
\text { filtrate }(\boldsymbol{\%})\end{array}$ & $\begin{array}{c}\text { Mycelial } \\
\text { growth }(\mathbf{c m})\end{array}$ & $\begin{array}{c}\text { \% inhibition } \\
\text { over control }\end{array}$ \\
\hline 1 & 0.01 & 2.7 & 46.0 \\
\hline 2 & 0.05 & 1.4 & 72.0 \\
\hline 3 & 0.1 & 0.35 & 93.0 \\
\hline 4 & Control & 5.0 & 0.00 \\
\hline
\end{tabular}


Table.2 In vitro effect of fungal and bacterial antagonists against $M$. phaseolina (Dual culture technique)

\begin{tabular}{|c|c|c|c|}
\hline S.No. & Isolates & $\begin{array}{c}\text { Mycelial growth } \\
(\mathbf{c m})\end{array}$ & $\begin{array}{c}\text { \% inhibition over } \\
\text { control }\end{array}$ \\
\hline 1 & T.viride & 1.30 & 85.41 \\
\hline 2 & P.fluorescens & 1.46 & 83.62 \\
\hline 3 & Control & 8.90 & 0.00 \\
\hline
\end{tabular}

Table.3 Efficacy of bio control agent on plant growth promotion under in vitro condition (Roll towel method)

\begin{tabular}{|c|c|c|c|c|c|}
\hline S.No. & Treatments & Germination \% & Root length $(\mathbf{c m})$ & Shoot length(cm) & Vigour index \\
\hline 1 & T. viride & 97 & 22.2 & 16.5 & 3753.9 \\
\hline 2 & P. fluorescens & 84 & 20.2 & 15.2 & 2973.6 \\
\hline 3 & Control & 72 & 12.7 & 9.7 & 1612.8 \\
\hline
\end{tabular}

However, among the treatments tested, $T$. viride was found to be the best as it recorded the maximum germination percentage $(97.00 \%)$, root length $(22.2 \mathrm{~cm})$, shoot length $(16.5 \mathrm{~cm})$ and vigour index $(3753.9)$ of black gram.

The control recorded the lowest value of germination percentage $(72 \%)$, root length $(12.7 \mathrm{~cm})$, shoot length $(9.7 \mathrm{~cm})$, vigour index (1612.8) of black gram (Table 3). Similar results had been obtained by Kredics et al., (2001) and Yedidia et al., (2001) where plant growth was improved by inoculation with Trichoderma spp., which also lead to early emergence and increased vigour of plants.

In the present investigation, application of bio-inoculants improved the growth parameters of black gram in all the treatments except control.

Among the antagonists the antagonistic culture filtrates of $T$. viride showed maximum seed germination and growth parameters (Fig. 2 ). The enhancement of seed germination and growth of seedling by culture filtrates of antagonists might be attributed to several factors such as the plant growth promoters, fungi toxic action leading to killing of fungal inoculums present in the seeds both internally and externally.

Similar results of plant growth promotion due to application of $P$. fluorescence and Trichoderma spp. was reported earlier by several workers (Raguchander et al., 1993).

The biocontrol agents not only controlled dry root rot but also promoted plant growth, and this gives them an advantage over the use of chemical fungicides against root rot in disease management. The work has to be intensified to study the mechanisms involved in disease control by mixtures of biocontrol agents.

\section{References}

Abdul Baki, A. A., Anderson, J. D. 1973. Vigour determination in soybean seed by multiple criteria. Crop Sci. 13: 630-633.

Dennis, C., Webster, J. 1971. Antagonistic properties of species groups of Trichoderma 1. Production of non-volatile antibiotics. Transactions of the British Mycological Society. 57: 25-39.

Dhingra, O.D., Sinclair, J.B. 1985. Basic Plant Pathology Methods. CRC Press, Inc. Boca Raton, Florida. Pp132-163. 
Kendig, S.R., Rupe, J.C., Scott, H.D. 2000. Effect of irrigation and soil water stress on densities of Macrophomina phaseolina in soil and roots of two soybean cultivars. Plant Dis. 84: 895-900.

Kredics, L., Antal, Z., Manczinger, L., Nagy, L. 2001. Breeding of mycoparasitic Trichoderma strains for heavy metal resistance. Applied Microbiology, 33: 112116.

Kumar, R., Honda, I. 2007. Integrated management of damping off of tomato caused by Pythium aphanidermatum. J. Mycology and Plant Pathology. 37: 259-262.

López-Herrera, C. J., Zea-Bonilla, T. 2007. Effects of benomyl, carbendazim, fluazinam and thiophanate methyl on white root rot of avocado. Crop Prot. 26(8):1186-1192.

Mayek-Perez, N., Lopez-Castaneda, C., GonzalezChavira, M., Garcia-Espinosa, R., AcostaGallegos, J., M. De-la-vega, O., Simpson, J. 2001. Variability of Mexican isolates of Macrophomina phaseolina based on pathogenesis and AFLP genotype. Plant Pathol. 59 (5): 257- 264.

Omar, I., O'neill, T. M., Rossall, S. 2006. Biological control of Fusarium crown and root rot of tomato with antagonistic bacteria and integrated control when combined with the fungicide carbendazim. Plant pathology. 55(1): 92-99.

Pearson, C.A.S., Schwenk, F.W., Crowe, F.J., Kelly, K. 1984. Colonization of soybean roots by Macrophomina phaseolina. Plant Dis. 68: 1086-1088.

Pun, K.B., Sabitha, D., Valluvaparidasan, V. 1998. Studies on seed-borne nature of Macrophomina phaseolina in okra. Plant Dis Res, 13:249-90.

Raguchander, T., Rajappan, K., Samiyappan, R. 1998. Influence of bio control agents and organic amendments on soybean root rot. Int. J. Trop. Agric. 16:247-252.
Rangaswami, G., 1993. Diseases of crop plants in India. Prentice Hall of India Pvt. Ltd., New Delhi, India. 1972; 520.

Scala, F., Raio, A., Zonia, A., Lorito, M. 2007. Biological control of fruit and vegetable diseases with fungal and bacterial antagonists: Trichoderma and Agrobacterium. In: Chincholkar SB, Mukerji KG (eds) Biological control of plant diseases. Howorth Press, Binghamton, pp 150-190.

Sinclair, J. B., 1982. Compendium of soybean diseases, $2^{\text {nd }}$ ed. American Phyto Pathological Society, pp. 104.

Singh, P.P., Shin, Y.C., Park, C.S., Chung, Y.R. 1999. Biological control of fusarium wilt of cucumber by chitinolytic bacteria. Phytopathology. 89: 92-99.

Srivastava, A. K., Singh, T., Jana, T.K., Arora, D.K. 2001. Microbial colonization of Macrophomina phaseolina and suppression of charcoal rot of chickpea. In Microbes and Plants, Sinha A (e d). Vedams eBooks (P) Ltd, New Delhi; 269-319.

Sundravadana, S., 2002. Management of blackgram [Vigna mungo (L.) Hepper] root rot Macrophomina phaseolina (Tassi) Goid with bio agents and nutrients. M.Sc. (Ag.) Thesis, Tamil Nadu Agricultural University, Coimbatore, India.

Vey, A., Hoagland, R.E., Butt, T.M. 2001. Toxic metabolites of fungal biocontrol agents. Fungi as biocontrol agents: progress, problems and potential. In: Butt TM, Jackson CN (Eds) CAB International, Bristol, pp 311-346.

Vincent, J. M., 1947. Distoration of fungal hyphae in the presence of certain inhibitors. Natur.159: 850.

Yedidia, I., Chet, I. 2001. Effect of Trichoderma harzianum on micro element concentrations and increased growth of cucumber plants. Plant Soil. 235: 235-242.

\section{How to cite this article:}

Athira K. 2017. Efficacy of Fungicide and Bio-Control Agents against Root Rot of Black Gram (Vigna mungo L.) caused by Macrophomina phaseolina (Tassi) Goid. Int.J.Curr.Microbiol.App.Sci. 6(10): 2601-2607. doi: https://doi.org/10.20546/ijcmas.2017.610.306 